\author{
自由電子レーザーとイオン照射によるポリスルフォン表面への \\ ヘパリンの固定化 \\ 日比野 豊, 徐 國春, 粟津 邦男* \\ (株) イオン工学研究所 (⿳573-0128 大阪府枚方市津田山手2-8-1) \\ *大阪大学大学院 工学研究科 自由電子レーザー研究施設 ( $5573-0128$ 大阪府枚方市津田山手2-9-5)
}

\title{
Specific Immobilization of Heparin on Polysulfone Films by Free Electron Laser and Ion Irradiation
}

\author{
Yutaka HIBINO, Guochun XU, and Kunio AWAZU* \\ Ion Engineering Research Institute Corporation, 2-8-1 Tsuda-Yamate, Hirakata, Osaka 573-0128 \\ *Institute of Free Electron Laser, Graduate School of Engineering, Osaka University, \\ 2-9-5 Tsuda-Yamate, Hirakata, Osaka 573-0128
}

(Received August 31, 2000)

\begin{abstract}
A novel way for specific immobilization of heparin on polysulfone (PSF) via laser irradiation is summarized. Free Electron Laser (FEL) wavelengths tuned to 6.18 and $6.31 \mu \mathrm{m}$, the typical absorption band of carboxyl group of heparin and stretching absorption of aromatic rings in polysulfone respectively, were chosen to illuminate thin heparin film formed on PSF surfaces. The modification at the wavelength of $6.18 \mu \mathrm{m}$ resulted in surface hydrophilicity and resistance to platelet adhesion. Surface elemental analysis on XPS implied the bounding of heparin on polymer surface. On the contrary, the modification at the wavelength of $6.31 \mu \mathrm{m}$ showed no statistical difference with controls in terms of hydrophilicity as well as elemental composition. This effect of variation in laser wavelengths is considered as coming from the structural and environmental differences of light-absorbing groups.
\end{abstract}

Key Words: Free electron laser (FEL), Ion irradiation, Polysulfone, Heparin

1. はじめに

生体用高分子表面に対する改質反応は, グラフト重合, 化 学接合, 単分子膜形成など種々の手法が検討され, 臨床で も polyethylene oxide, ビタミンE修飾したポリスルフォン血 液透析器が使用されている1-7)。しかしながら現状では何 れもの場合でも血液と接する材料表面での血栓形成を防 止するには,抗血栓剤を同時に投与するなどの方法を講じ なければならない。
この時の抗血栓剂として多くはへパリンが使用される が, 大量にかつ継続的に使用すると, 副作用が見られるこ とが問題視されている。このため,へパリンを生体用材料 表面へ固定化することが可能になれば非常に有用であ る.

Fig. 1に本実験に用いたへパリンとポリスルフォン (PSF と略す)の分子構造を示す。ヘパリンは人体の血液中に含 まれる血液凝固阻止作用をもつ多糖類の一種であるが, 糖 鎖のヒドロキシル基が硫酸基, アミン硫酸基, カルボキシ

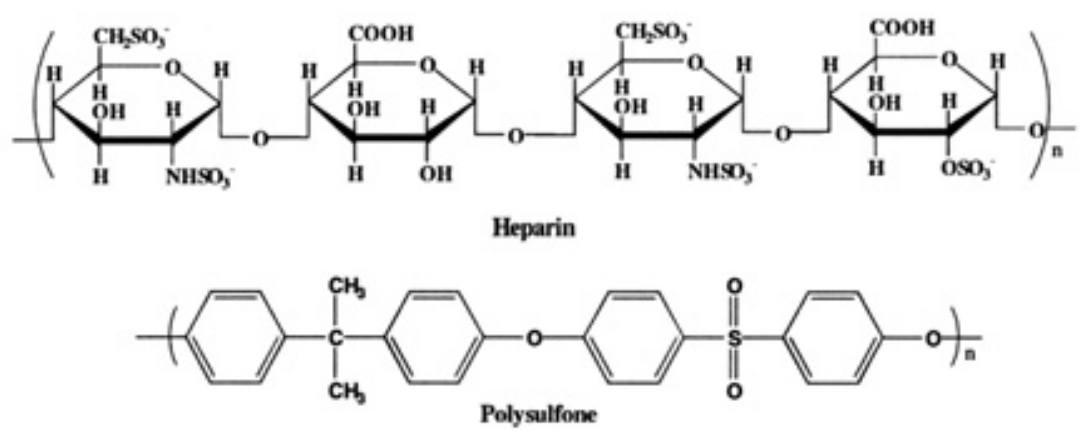

Fig. 1 Molecular structure of heparin and PSF. 
ル基に置き換えられたものである.PSFは酸素, スルフォ ンとイソプロピルを介在したベンゼン環を4ケ結合した高 分子である.

このような分子構造を示すへパリンの固定化方法は今 までに2つの方法が採用されている8-12). その1つは, イオ ン相互作用による方法で, マイナス電荷のへパリンを材料 表面に化学的に作用させアンモニウム塩を固定する方法 である。しかし静電的に結合したへパリンは, 血流中で繰 り返して使用すると容易に脱落するために, 抗血栓性が短 期間しか持続し得ない欠点がある.2つ目は共有結合によ る方法である．共有結合であることから長期間抗血栓性 を維持することが可能であるが,へパリンは水とフォルム アミドしか溶解することができないため, 固定化反応時に いくつかの変性が同時に起こり, 抗血栓性が低下する報告 がある。

そこで我々は自由電子レーザー (FEL) とイオンビーム照 射とのそれぞれの特徴を組み合わせて,ヘパリンを固定化 する方法を検討した。

FELは任意の波長での発振が可能であることから, 特定 の官能基だけを励起し活性化して反応させることができ る13). 一方, イオンビーム照射は任意の元素を任意の深さ に任意の量だけ入れることにより,材料表面の形態(モルホ ロジー)を変化させたり,化学結合状態を変え酸化による極 性基を生成させたりすることができる14).

本研究では任意の生理活性物質を選択的に固定化する 技術を研究開発することを狙い, イオン照射により親水化 されたPSF表面にへパリンをコーティングし,へパリンの カルボキシル基とPSFのベンゼン環の吸収波長に対応する FELを用いて,ヘパリンをPSF表面に選択的に固定化する手 法を検討した。

\section{2. イオン, FEL照射試料及び試験条件}

本研究においては生理活性物質として血液凝固防止剂 であるへパリンを選定し, 人工透析膜等の素材として使用 されているPSFを選定した. 実験では,イオン工学センター 所有の $200 \mathrm{keV}$ イオン注入装置を利用して, イオン照射にお ける反応の予備実験を行いその中から条件を選定した。

FELは自由電子レーザー研究所所有の電子リニアッ ク, FEL装置を利用した。

本装置は $0.5 \mathrm{~ns}$ パルスで $1 \sim 4 \mathrm{~A}$ の電子ビーム入射が可能 な電子銃を備えた電子入射器, $24 \mu \mathrm{s}$ 長パルス・クライスト ロンパルサー, 電子ビームの 22.5 度偏向輸送系及びアン ジュレーターを組み合わせた装置で, $100 \sim 0.23 \mu \mathrm{m}$ の任意 な波長を得ることができるものである。そこで前述した ヘパリンとPSFの分子構造からどのような波長で照射すれ ば効果的に反応できるか検討を行った。

ヘパリンとPSFのFTIRスペクトルをFig. 2に示す。この 中で波長 $6.18 \mu \mathrm{m}$ の大き吸収ピークは,ヘパリンのカルボ キシル基の吸収によるものであり, 波長 $6.31 \mu \mathrm{m}$ はPSFのべ ンゼン環の伸縮振動による吸収ピークであることが知ら れている.

ヘパリンのスルフォン基やアミノ基に由来する側鎖は,

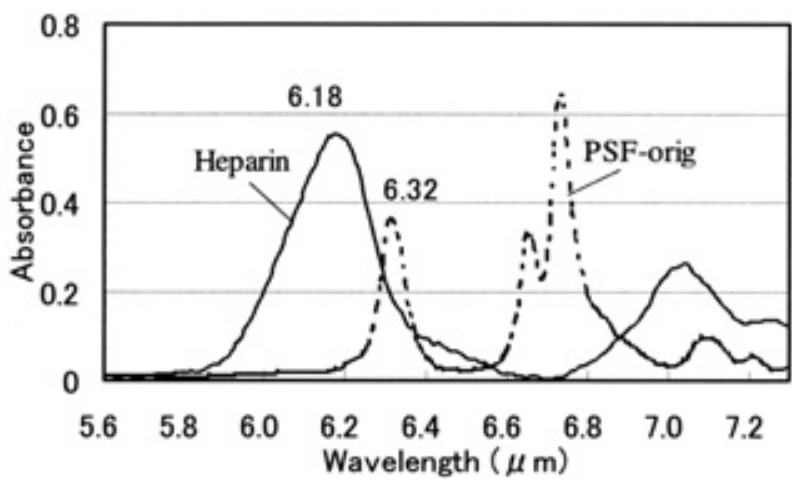

Fig. 2 IR absorption spectra of heparin and PSF.

抗血栓性に寄与していると言われており,この部分を変化 させると抗血栓性に影響を及ぼす恐れがあることから, カ ルボキシル基を励起して固定化させることを目的として, 波長6.18 $\mu \mathrm{m}$ のレーザーを選定し, またエーテル結合, スル フォン結合を変化させずにPSFの芳香族環部分を励起して 反応させることを狙い, 波長 $6.31 \mu \mathrm{m}$ のレーザーを選定し た。

\section{1 ヘパリンコーティング方法}

実験に用いたPSFは0.1 mmフィルムをエタノールで超音 波洗浄後, Table 1の条件にて処理した。フィルムへのイオ ン照射は先行実験で効果の大きかった $150 \mathrm{keV}, 10^{16}$ ions/ $\mathrm{cm}^{2}$ で $\mathrm{O}^{+}$照射した。 またフィルムへのへパリン水溶液を コーティングする際に, 水溶液のみでは表面張力が大きく PSF表面からはじかれるため, $10 \%$ のエタノールを含む1\% ヘパリン水溶液を用い, 約 $0.5 \mathrm{~cm}^{2}$ 当たり $60 \mu \mathrm{l}$ 滴下し, 自然 乾燥させてコーティング作業を行った.

さらにFEL照射条件は出力 $23 \mathrm{~mW}$ (平均)の特定波長の レーザーで,パルス幅数ps (ミクロパルス), 繰り返し数 330 パルス(ミクロパルス/マクロパルス) 10 パルス(ミクロパ ルス $/ \mathrm{sec}$ ), 照射強度 $46 \mathrm{~mW} / \mathrm{cm}^{2}$ (平均), 照射面積 $0.5 \mathrm{~cm}^{2}$ で 5分間スキャニングすることにより試料全面を照射した。 またすべての試料は, 表面処理後純水で3回以上洗浄して, 固定化されなかったへパリンを取り除き, 乾燥後に分析評 価を行った。

\section{2 固定化されたへパリンの定量}

固定化されたへパリンの測定はトルイジンブルー (TB) 法で実施した。ヘパリンはトルイジンブルーと反応して 複合物を形成し, 形成した複合物はへキサンで分液すると 有機層に移転する。これにより水溶液に残っている未反 応なトルイジンブルーの吸収減少からへパリンの量を計 算した。具体的には $3 \mathrm{ml}$ の一定濃度のTB溶液と $2 \mathrm{ml}$ の一定 濃度のへパリン溶液を 10 分間ミキサーで混合して, $3 \mathrm{ml}$ の ヘキサンを加え5分間ミキシングして遠心分液した。その 後水溶液層をUVセルに移しUVスペクトルを測定した。へ パリンの量によるUV吸収の変化から検量線を引き固定化 されたへパリンの量を計算した。 
Table 1 Combination of experiments and names of the samples.

\begin{tabular}{cccc}
\hline & Ion irradiation & Heparin coating & Laser illumination \\
\hline PSF-orig & no & no & no \\
PSF-oh & no & yes & no \\
PSF-ol & no & no & yes \\
PSF-ohl & no & yes & yes \\
\hline PSF-i & yes & no & no \\
PSF-ih & yes & yes & no \\
PSF-il & yes & no & yes \\
PSF-ihl & yes & yes & yes \\
\hline
\end{tabular}

PSF-orig : no disposal. PSF-oh : only heparin coating. PSF-ol : only laser illumination. PSF-ohl : laser illumination after heparin coating. PSF-i:only ion irradiation. PSF-ih: heparin coating after ion irradiation. PSF-il: laser illumination after ion irradiation. PSF-ihl: laser illumination after ion irradiation and heparin coating.

\section{3 表面の濡れ性}

生体用高分子表面に対する水に対する前進接触角は血 液の凝固性と関係することが知られており, 光学的接触角 測定装置を用い純水で $25{ }^{\circ} \mathrm{C}$ 大気中にて測定した。

\section{4 表面の化学的構造変化}

イオン照射後における生体用高分子材料の分子結合の 変化は赤外分光分析器 (FT-IR) 法では検出できないため, 表 面元素組成と化学結合状態を光電子分光分析装置 (XPS)に より分析評価した。

\section{5 抗血栓性評価}

血液中に含まれる血小板は血液凝固阻止剤によって凝 固しないが, 異種材料に触れたり環境が変化したりすると 一過性の止血栓として働く。この血小板の緩い凝着体は フィブリンの作用によって固められ最終的な凝血とな る.これらのことから試料表面に新鮮な血液を作用させ, 血小板の粘着数を調べることによって抗血栓性が評価さ れる. 今回は新鮮血液に $3.2 \%$ クン酸ナトリウム溶液を 添加したリン酸緩衝溶液を用いて, 照射試料表面への血小 板粘着性を一定時間作用させた後, 走査型電子顕微鏡 (SEM)を用いて形状と粘着数を観察した.

\section{3. 実験結果及び考察}

\section{1 イオン及びFEL照射表面のモルホロジー}

高エネルギーのイオン照射によって材料表面では分解 や架橋によりモルホロジーが変化することが報告されて おり, 今回のPSF表面では, 照射後に表面粗さが $2 \sim 3 \mathrm{~nm}$ に なると言うこと, また照射量が増大するに従い黄色から褐 色に着色して表面層でグラファイト構造化することが観 察された。このような表面にFEL照射すると, PSF表面は Fig. 3に示すようにレーザーの波長により大きく変わるこ とが観察された。すなわちPSFの主骨格の芳香族環に影響 しないカルボキシル基の $6.18 \mu \mathrm{m}$ 波長では, 外観上ほとんど 変化しない平滑な表面であるのに対して, PSF主骨格の芳
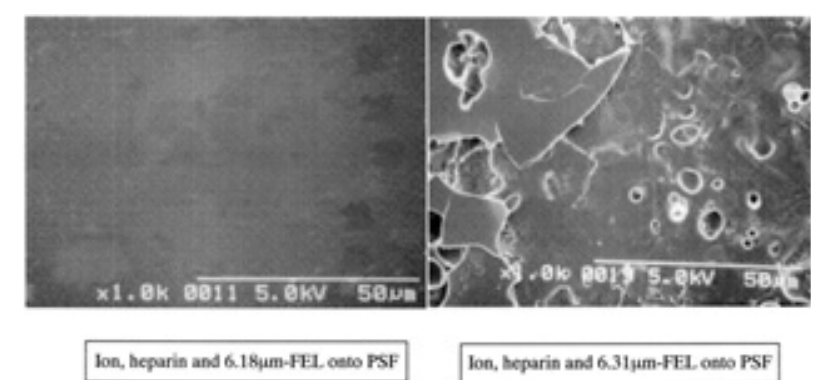

lon, heparin and 6.31um-FEL onto PSF

Fig. 3 Morphology of PSF surface irradiated by $6.18 \mu \mathrm{m}$ FEL (left) and $6.31 \mu \mathrm{m}-\mathrm{FEL}$ (right).

香族環の励起波長 $6.31 \mu \mathrm{m}$ では, 表面層が数十 $\mu \mathrm{m}$ サイズで 破壊され,アモロファス化したカーボン層も分解により白 化した。

またPSF表面には, 両表面共にへパリンがコーティング されているにもかかわらず, $6.18 \mu \mathrm{m}$ 波長で照射したサンプ ルは,コーティングされたへパリンの外観変化は認められ ず,へパリンそのものには大きなダメージを与えていない ものと推察された.

これらのことから分子構造面から励起波長を選定する ことは非常に重要であり,へパリンの固定化には6.31 $\mu \mathrm{m}$ は母材そのものへの影響があり, 固定化には適さないこと が判り, $6.18 \mu \mathrm{m}$ の励起波長はへパリンを破壊しないで固定 化できるものと考えられる。

\section{2 固定されたへパリンの測定}

上記理由から $6.31 \mu \mathrm{m}$ 照射ではへパリンの測定が困難で あることから, $6.18 \mu \mathrm{m}$ 照射による固定されたへパリンの量 をトルイジンブルー (TB) 法で測定した. その結果をFig. 4 に示す。

この結果, イオン未照射でレーザー照射したPSF表面 (PSF-ohl)に固定化されたへパリンの量は $1.17 \mu \mathrm{g} / \mathrm{cm}^{2} て ゙$ あった。一方これにイオン照射したPSF表面 (PSF-ihl)に固 定化されたへパリンの量は $1.38 \mu \mathrm{g} / \mathrm{cm}^{2}$ であるが, レーザー 照射しなくても, イオン照射のみのPSF表面(PSF-ih)に固定 化されたへパリンの量は $0.4 \mu \mathrm{g} / \mathrm{cm}^{2}$ であった。これらか 


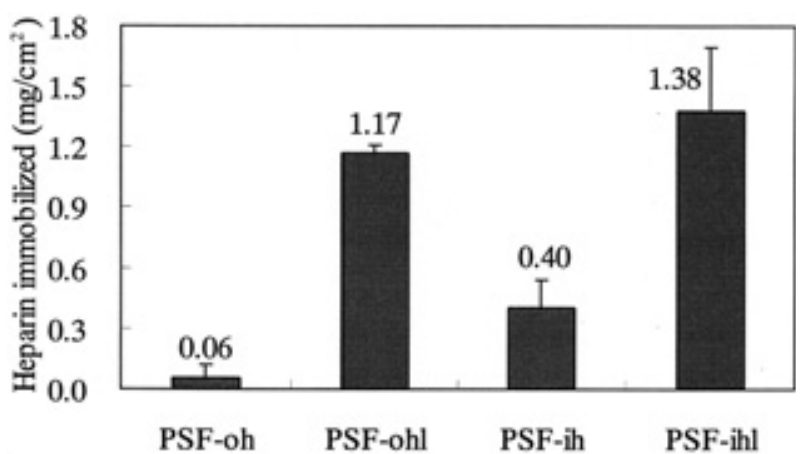

Fig. 4 Amount of heparin immobilized on the PSF surface.

ら,各々のデーターの有意差を統計分析した結果をTable 2 に示す。

表のFELIはFEL照射, PBIIはイオン照射を意味する。 ANOVA (ANalysis of VAriation) とtTest (Student test) 共にp く0.05を示しており解析方法の有意差を確認した。この結 果から, FEL照射とイオン照射はへパリンの固定化に貢献 することが判り,この中でFEL照射のF-ratioがより大きいこ とから, FEL照射は特にへパリンの固定化に大きく貢献す ることが判った。

以上の結果から, イオンもFELも照射しないPSF表面で は,へパリンをコーティングしても水溶性のへパリンは洗 い流されてほとんどPSF表面に付着しないし, またイオン 照射後にへパリンコーティングするのみでもわずかな付 着量しか得られないことが判った。 これに対して波長 6.18 $\mu \mathrm{m}$ のEL照射を行った表面, およびイオン照射とFEL照射 を併用したPSF表面では, 未処理の20倍以上の量が固定化 されていることが判った。この原因はFEL照射がへパリン のカルボニル基を励起してラジカルを生成し, イオン照射 によってPSF表面の生成しているヒドロキシル基やカルボ キシル基と再結合したものと推定され,これによりへパリ ンの固定化量が多くなったものと考えられる.

\section{3 表面の濡れ特性}

各照射試料について水の接触角測定結果をFig. 5に示 す。この結果, イオン未照射試料やそれぞれの単独処理の みでは接触角が80度以上を示し, それらの変化は誤差範囲 内であった。一方へパリンをコーティングしてレーザー 照射した試料では接触角が71度に下がり, PSF表面はより 親水性になった。イオン照射試料後へパリンコーティン グした試料では低い接触角の值 (64度)が見られ, イオン照 射十へパリンコーティング+レーザー照射した試料では 接触角が66度となり, いずれも親水性表面が得られること

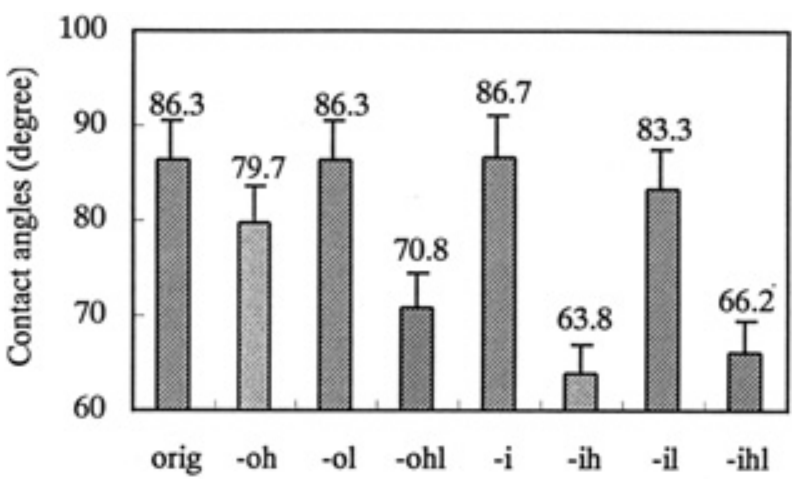

Fig. 5 Contact angle of water on the sample surface.

が判った。このことは上記のへパリン固定化量と関係し ているものと考えられる。

\subsection{XPSによる表面化学分析}

PSF表面層の化学組成を調査するため, 室温乾燥させた 試料を $10^{-7}$ Torrの真空中に16時間脱気してから $5 \times 10^{-9}$ Torr の真空中でXPS分析を行った，その典型的な照射条件にお ける炭素, 酸素, 窒素と硫黄の原子存在比 $(\%)$ をTable 3 に 示す.

これからも判るように,イオン照射により表面酸素ピー クが増加し硫黄ピークが低下した。ヘパリンコーティン グした試料にFEL照射した試料では, 酸素ピークが大幅に 増加し, 元々含んでいない窒素も検出され,ヘパリンが表 面に固定化されたことを裏付けていると思われる。

Fig. 6にヘパリン材料とPSFオリジナル, PSF-ohlのS 2 p XPSスペクトル, Fig. 7にPSFオリジナルとPSF-i, PSF-ihlの S2p XPSスペクトルを示す.このヘパリンとPSFのS2p XPS スペクトルをピーク分離すると,ヘパリンのS $2 \mathrm{p}_{1 / 2}$ と $\mathrm{S} 2 \mathrm{p}_{3 / 2}$

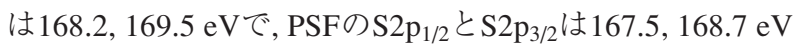
であることが判る。これらのピーク分離結果を用い, PSFohlのS2pXPSスペクトルを分離した結果を破線で示す。こ のことからPSF表面のオリジナルとへパリンのオリジナル スペクトルの中間的なエネルギーシフトパターンを示し ていることが判り, PSF表面に対してへパリンのサルファ と考えられる結合形式が存在しているものと思われる.

Fig. 7から, PSFへイオン照射するとS2p XPSスペクトル のS2pピークは低い結合エネルギー側にシフトすることが 判る。この現象はイオン照射により一部の結合が切断さ れたり, 脱水素や酸化が起きたりして, スルフォンがサル ファイドに変わったものと見られた. PSF-iとPSF-ihlのS2p XPSスペクトルを比較すると, PSF-ihlの方は $168.7 \mathrm{eVでの}$

Table 2 Examination of statistical difference of heparin immobilized on the PSF surface.

\begin{tabular}{cccccc}
\hline Source & \multicolumn{3}{c}{ Analysis of Variance } & \multicolumn{2}{c}{ t Test } \\
& Sum of square & F-ratio & Probability & t Value & Probability \\
\hline FELI & 18.871 & 455.330 & 0.000 & -18.614 & 0.000 \\
PBII & 1.324 & 31.949 & 0.000 & -2.048 & 0.046 \\
FELI*PBII & 0.074 & 1.779 & 0.186 & & \\
\hline
\end{tabular}


Table 3 Elemental composition of each sample surface obtained from XPS analysis.

\begin{tabular}{ccccc}
\hline Substrates & C1s & O1s & S2p & N1s \\
\hline Heparin & 46.2 & 45.5 & 4.9 & 3.3 \\
PSF & 82.6 & 14.8 & 2.6 & \\
PSF-ohl & 64.1 & 29.1 & 3.8 & 3.0 \\
PSF-i & 80.0 & 17.9 & 2.1 & \\
PSF-ihl & 67.0 & 26.7 & 3.3 & 2.9 \\
\hline
\end{tabular}

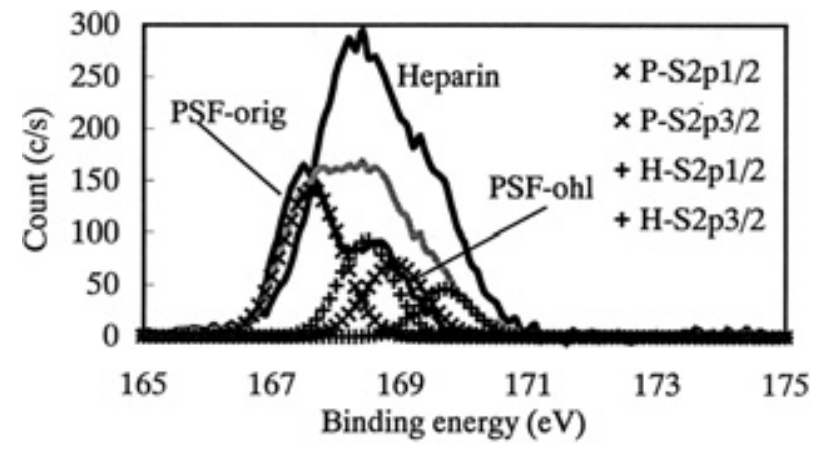

Fig. 6 S2p XPS spectra of heparin, PSF-o and PSF-ohl.

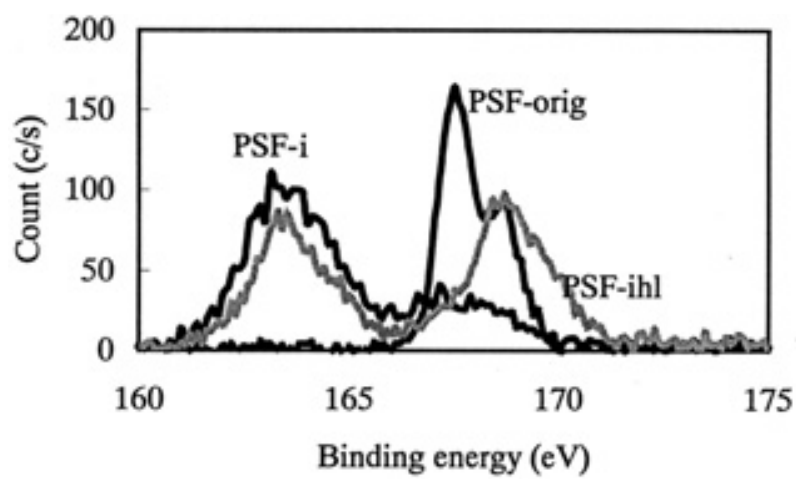

Fig. 7 O1s XPS spectra of heparin, PSF-o, PSF-i, PSF-ohl and PSF-ihl.

ピークが見られる。これらのことからPSF表面にイオン照 射しへパリンを作用させてFEL照射することにより,へパ リンのサルファと考えられる結合形式がPSF-ihl表面に形 成されたものと思われる。同様にして酸素と炭素につい ても同様にXPSスペクトルのピーク分離を行った結果, 十 分な分解能が得られにくいため信頼性があるピーク分離 ができないが,スペクトルの形だけを比較するとへパリン の固定化はされていると考えられた.

\section{5 抗血栓性評価の結果}

PSF表面への処理条件と血小板粘着数の関係をFig. 8に示 す。イオン注入直後にへパリンをコーティングすること により PSF表面に親水性となり, 血小板の粘着に大きい影 響を与えることが判った。

このためイオン照射有無により, FEL照射(FELI) とへパ リンのみ (HEP) とその相乗効果 $($ FELI*HEP)によって, 血小 板粘着性にどのように影響するかを統計的に解析した。 統計分析した結果をTable 4に示す.

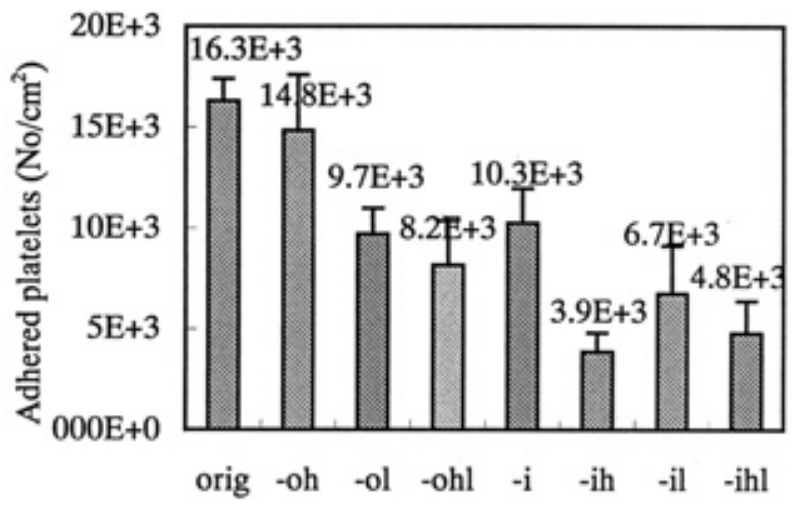

Fig. 8 Conditions of Treatments for PSF surface and number of immobilized blood platelets.

PSF表面にイオン照射しない組(No)では, FEL照射に対 し, ANOVAとtTest共に $p<0.05$ の值を示し, FELを照射する 方法の有意差を確認した。すなわちFEL照射はPSF表面へ のへパリンの固定化に貢献していることが判った。また ヘパリンのコーティングに対しては, $p>0.05$ の值を示して おり有意差がないと判断された。

一方,イオン照射した組(Yes)では, FEL照射に対し, $p>$ 0.05 の值を示しており有意差がないと判断されたが,へパ リンのコーティングに対しては, ANOVAとtTest共に, $p<$ 0.05を示しイオン注入法の有意差を確認した。

以上のことから，イオン照射によってPSF表面では分子 切断が起き, 生成ラジカルが空気中の酸素や水分と反応し てヒドロキシル基やカルボキシル基が生成され,これがへ パリンのコーティング性を改善し,ささらにFEL照射がへパ リンの特定部位を励起してヘパリンの固定化に寄与して いるものと考えられる。

$$
\text { 4. まとめ }
$$

生体用高分子材料の高機能化を目的として, PSF表面へ のイオンとFELの複合照射を試み, 血液凝固阻止剂である ヘパリンを固定化する方法を検討した.

各種分析結果及び統計的解析結果から, イオン照射と FEL照射はへパリンの固定化に貢献することが判り, 最高 $1.38 \mu \mathrm{g} / \mathrm{cm}^{2}$ のヘパリンを固定化できることがわかった.

このようなへパリンの固定化プロセスは,イオン照射, へ パリンのコーティングとFEL照射の3つのステップを通し て次のような反応を起こしているものと考える.

PSFフィルムは150 keVのエネルギーで照射されること 
Table 4 Examination of statistical difference of ion and laser irradiation methods.

\begin{tabular}{ccccccc}
\hline \multirow{2}{*}{ PBII } & \multicolumn{2}{c}{ Analysis of Variance } & \multicolumn{2}{c}{ t Test } \\
& Source & Sum of & F-ratio & Probability & t Value & Probability \\
& & square & & & & \\
\hline \multirow{2}{*}{ No } & FELI & $3.53 \times 10^{8}$ & 80.270 & 0.000 & 8.654 & 0.000 \\
& HEP & $1.83 \times 10^{7}$ & 4.160 & 0.051 & 1.073 & 0.292 \\
& FELI*HEP & $9.88 \times 10^{3}$ & 0.002 & 0.963 & & \\
\hline \multirow{2}{*}{ Yes } & FELI & $1.35 \times 10^{7}$ & 3.936 & 0.057 & 1.214 & 0.236 \\
& HEP & $1.40 \times 10^{8}$ & 40.710 & 0.000 & 5.308 & 0.000 \\
& FELI*HEP & $3.92 \times 10^{7}$ & 11.410 & 0.002 & & \\
\hline
\end{tabular}

により, PSF表面では一部の分子結合が切断され, その部位 でラジカルなどが生じて活性化される。この生成ラジカ ルはその後へパリンをコーティングするとき,特にイオン 照射した直後に活性化された状態で, 溶媒とする水, 溶質 とするへパリンと接することにより一部反応して親水性 となり, 乾燥してもへパリン膜との密着性が優れたものと なる，FEL照射においては, その照射波長は重要で, 波長 $6.31 \mu \mathrm{m}$ ではPSF表面そのものが破壊されるが, 波長 $6.18 \mu \mathrm{m}$ で照射すると,へパリン表面のカルボニル基 $(-\mathrm{C}=\mathrm{O})$ がFEL 光を吸収し励起され, PSF表面と化学的に反応することに よりへパリンが固定化されるものと考える.これらのこ とからイオン照射とFEL照射の複合照射の有用性が明らか になった。また本実験材料以外にポリエチレン材料, ポリ テトラフルオロエチレン材料についても評価を行った結 果, 同様な結果を得ており, このような技術は他の材料表 面の改質にも有用と考えられる。

\section{謝 辞}

本研究は科学技術庁の平成 11 年度科学技術振興調整費 による「QOLを指向した生体融和材料の新創出に関する研 究」の一環として実施したものである，関係各位に感謝し ます。有益な助言を戴いた奈良先端大学院大学今西幸男 教授, 谷原 正夫教授に深謝します。また原稿整理に協力を 得た深見裕子氏に感謝します。

\section{参考文献}

1) R. J. Zdrahala: J. Biomater. Appl. 10 (1996) 309.

2) Y. Ito and Y. Imanishi: J. Biomater. Appl. 6 (1992) 293.

3) G. Khang, J. B. Park, and H. B. Lee: Biomed. Mater. Eng. 6 (1996) 47.

4) G. Clarptti, F. Schue, J. Sledz, A. ait ben Aoumar, K. E. Geckeler, A. Orsetti, and G. Paleirac: Biomaterials 13 (1992) 832.

5) K. J. Kim, A. G. Fane, and C. J. D. Fell: J. Membrane Sci. 43 (1989) 187.

6) T. Aoike, I. Teramura, Y. Suzuki, F. Gejyo, and M. Arakawa: Jpn J. Artif. Organs 24 (1995) 685.

7) Y. Sato, K. Ito, H. Amemiya, T. Kobayashi, S. Uda, F. Koiwa, K. kino, E. Kinugasa, T. Akizawa, T. Ideura, and K. Tanigaki: Jpn. J. Artif. Organs 26 (1997) 858

8) D. K. Han, S. Y. Jeong, and Y. H. Kim: J. Biomed. Mater. Res. Appl. Biomater. 23 (1989) 211.

9) M. Amiji and K. Park: J. Biomater. Sci. Polymer Edn. 4 (1993) 217.

10) K. Kang, O. H. Kwon, M. K. Kim, Y. M. Lee, and Y. K. Sung: Biomaterials 18 (1997) 1099.

11) M. Yang, Y. J. Jong, K. Y. Hsu, and C. H. Chang: J. Biomed. Mater. Res. 39 (1998) 86.

12) W. Marconi, F. Benvenuti, and A. Piozzi: Biomaterials 18 (1997) 885 .

13) H. Mirzadeh, A. A. Katbab, M. T. Khorasani, R. P. Burford, E. Gorgin, and A. Golestani: Biomaterials 16 (1995) 642.

14) Xu. Guo-chun, Y. Hibino, Y. Suzuki, Y. K. Kurotobi, M. Osada, M. Iwaki, M. Kaibara, M. Tanihara, and Y. Imanishi: Colloids \& Surfaces B: Biointerfaces (in press). 